\title{
A Study of Community Leaders in a Nuclear Host Community: Local Issues, Expectations and Support and Opposition
}

\author{
B. H. Bronfman
}

\section{OAK RIDGE NATIONAL LABORATORY}




\section{DISCLAIMER}

This report was prepared as an account of work sponsored by an agency of the United States Government. Neither the United States Government nor any agency Thereof, nor any of their employees, makes any warranty, express or implied, or assumes any legal liability or responsibility for the accuracy, completeness, or usefulness of any information, apparatus, product, or process disclosed, or represents that its use would not infringe privately owned rights. Reference herein to any specific commercial product, process, or service by trade name, trademark, manufacturer, or otherwise does not necessarily constitute or imply its endorsement, recommendation, or favoring by the United States Government or any agency thereof. The views and opinions of authors expressed herein do not necessarily state or reflect those of the United States Government or any agency thereof. 


\section{DISCLAIMER}

Portions of this document may be illegible in electronic image products. Images are produced from the best available original document. 


\section{Printed in the United States of America. Available from National Technical Information Service \\ U.S. Department of Commerce \\ 5285 Port Royal Road, Springfield, Virginia 22161 \\ Price: Printed Copy $\$ 4.00$; Microfiche $\$ 3.00$}

This report was prepared as an account of work sponsored by the United States Government. Neither the United States nor the Energy Research and Development Administration/United States Nuclear Regulatory Commission, nor any of their employees, nor any of their contractors, subcontractors, or their employees, makes any warranty, express or implied, or assumes any legal liability or responsibility for the accuracy, completeness or usefulness of any information, apparatus, product or process disclosed, or represents that its use would not infringe privately owned rights. 
ORNL/TM-5997

Contract No. W-7405-eng-26

A STUDY OF COMMUNITY LEADERS IN A NUCLEAR HOST COMMUNITY: LOCAL ISSUES, EXPECTATIONS AND SUPPORT AND OPPOSITION*

B. H. Bronfman

Energy Division

Oak Ridge National Laboratory

Oak Ridge, Tennessee 37830

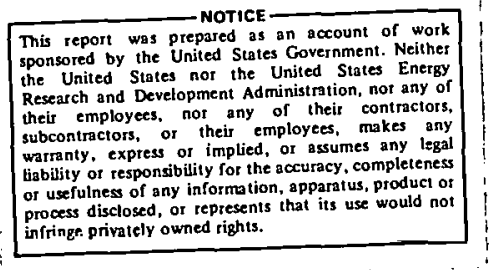

Date Published: August 1977

*Research sponsored by the Energy Research and Development Administration, Division of Technology Overview, under contract with the Union Carbide Corporation.

OAK RIDGE NATIONAL LABORATORY

Oak Ridge, Tennessee 37830

Operated by Union Carbide Corporation

for the Energy Research and Development Administration 


\section{Contents}

List of Figures .................. Page

List of Tables .................. . . . v

Acknowledgments ............................. vii

Abstract ...................... ix

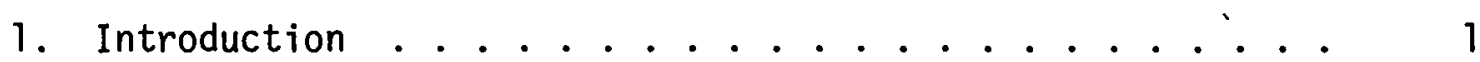

2. Purpose ........................ 4

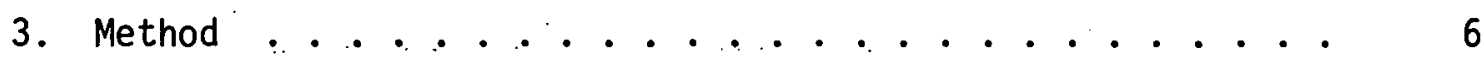

4. Results and Discussion ............... 8

4.1 Leadership Characteristics . . . . . . . . . . . 8

4.2 Leadership Support and Opposition ........ 10

4.3 Significant Local Issues............. . . 15

4.4 Community Values ................ . . . 16

4.5 TVA Mitigation Plan ............ . . 18

4.6 Community Satisfaction ............. . . 20

4.7 Expectations of Future Occurrences ......... 22

5. Summary and Conclusions ............. 23

Bibliography ........................... 25 


\section{PAGES iii to $\mathrm{v}$ WERE INTENTIONALLY LEFT BLANK}




\section{List of Figures}

$\underline{\text { Figure }}$

\section{List of Tables}

$\underline{\text { Table }}$

Site Characteristics ............. 3

2 Top Community Leaders . . . . . . . . . . . 8

3 Socioeconomic Status Characteristics of Leaders . . . 9

4 Support and Opposition to the Hartsville Nuclear Power Plant ............. 10

$5 \quad$ Adjusted Frequencies for Support and Opposition to the Hartsville Nuclear Power Plant ....... 11

6 Leaders' Estimates of Citizen Support of Nuclear Power Plant ................ 13

7 Important Issues Facing the Local Area . . . . . . 16

8 Community Value Orientation Ranking . . . . . 17

9 Involvement in Specific Issues ......... 18

10 Adequacy of Various Areas of Community Life . . . 2 21

11 Leaders' Expectations of Future Events . . . . . . 22 


\section{Acknowledgments}

The author wishes to thank those persons who assisted in the gathering of information and data presented in this report: Joyce Costomiris, David Darrohn, Robert DeVault, and Marion Pane11. Helpful reviews of this document were received from Lois Bronfman, Mark Shields, Richard Davis, Elizabeth Peelle, and Thomas Wilbanks. Special thanks go to the citizens of Hartsville and Trousdale County, Tennessee, who. provided most of the information used in this report, and whose continued cooperation is assisting us in understanding community social impacts. 
THIS PAGE

\section{WAS INTENTIONALLY LEFT BLANK}




\section{Abstract}

A study of community leaders was undertaken in Hartsville, Tennessee, site of the TVA Hartsville Nuclear Power Plant currentiy under construction. Leaders were found to be extremely supportive of the plant and of TVA's efforts to mitigate impacts expected to result from construction. Like their citizen counterparts, leaders expect economic benefits and some growth-related disruption to occur as a result of the plant, while environmental impacts are seen as extremely unlikely to occur. Plant-related issues, such as housing availability and traffic congestion, dominate leaders' thinking about current issues. These issues are expected to continue to be important in the future, and new issues dealing with growth and planning, employment and taxation are expected to arise. 


\section{Introduction}

This study is part of a continuing effort directed at assessing the social impacts of energy facility planning, construction, operation, and decommissioning upon communities. Two major questions underly the overall effort. First, how do communities react to facility-related impacts, and how do these reactions develop and evolve over time? Second, are there any social impacts which can be said to be common among energy facilities, or are there social impacts specific to a given energy technology?

To answer these questions, a time-series quasi-experimental research design (Campbell and Stanley, 1966) has been developed by the Social Impact Assessment Group at Oak Ridge National Laboratory. A summary of the design is presented in figure 1. As can be seen, various subjects are to be examined over time, including citizen attitudes, various social indicators, local decisions, mitigation plans, labor force housing, and service sector changes. Utilizing the time-series framework, the evolution of social impacts can be examined and changes in the type of impact or the magnitude of impacts can be related to utility licensing, facility construction, and local administrative decisions.

Further auymenling this approach and to address the problem of technology-related impacts, the social impacts of the Hartsville Nuclear Power P.lant, located primarily in Trousdale County, Tennessee, are being analyzed in a comparative framework with the Scherer (coal-fired) Plant, located in Forsyth (Monroe County), Georgia. Both plants represent state-of-the-art technologies, both are considered very large, and both are located in rural counties in proximity to urban centers. Both plants are expected to be completed at approximately the same time. Thus, the 


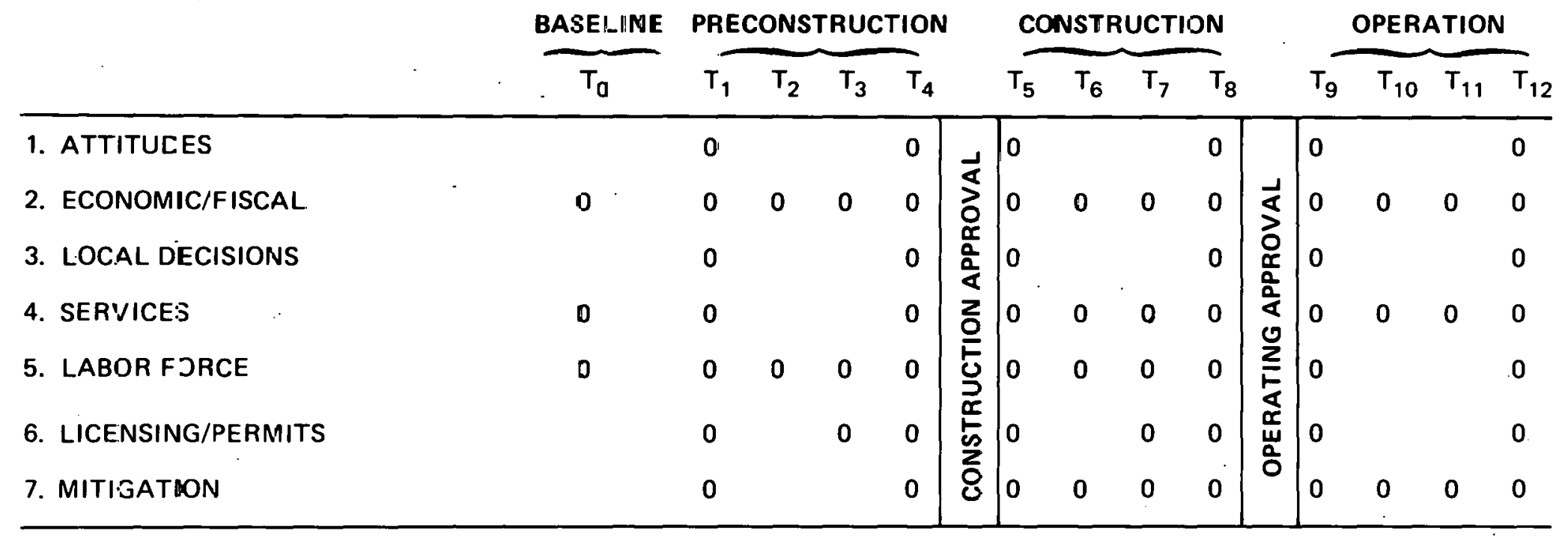

Figure 1. Hartsville-Forsyth Time Series Research Design. 
two sites, whose important characteristics are summarized in Table 1, provide a unique opportunity for examining comparative social impacts of alternative electricity generating technologies. (One major difference, which will be examined in later documents, is the taxation situation; TVA, as a public utility, makes only in lieu payments; while Georgia Power will be taxed as any private utility.)

Table 1. Site Characteristics

\begin{tabular}{lll}
\hline Name of facility: & Hartsville (nuclear) & Sherer (coal) \\
Location: & Hartsville, Tennessee & Forsyth, Georgia \\
Town population: & 2500 & 3700 \\
County: & Trousdale & Monroe \\
County population: & 5000 & 11000 \\
Nearest urban center: & Nashville & Macon/Atlanta \\
Population: & 450,000 & $120,000 / 450,000$ \\
Distance: & $45 \mathrm{mi}$. & $20 / 55 \mathrm{mi}$. \\
Number of units: & 4 & 4 \\
MwE/unit: & $1100+$ & $800+$ \\
MwE/total: & 4500 & 3300 \\
Begin construction: & Apri1 1976 & May 1977 \\
Schedule & Units Al \& B1 - 1983. & Unit 1 - 1981 \\
& Units A2 \& B2 - 1984 & Unit 2 - 1982 \\
& & Unit 3 - 1984 \\
& & Unit $4-1985$ \\
Peak construction force: & 5800 & 1500 \\
Peak year: & T981 & $1979-80$ \\
Utility: & TVA & Georgia Power Co. \\
\hline
\end{tabular}


To date, two general attitude surveys have been conducted at the Hartsville site (Schuller, et al., 1975; Sundstrom, et a1., 1977), and public records have been gathered and are being analyzed to establish trends in level of revenue, expenditures, and use of public services. This report will describe the current phase of the general study, which deals with community leaders and important local decisions affecting community life. Parallel studies are being conducted at the Forsyth site, and results will be reported in future publications.

\section{Purpose}

This report documents a study of community leaders in Hartsville, Tennessee, site of the Hartsville Nuclear Power Plant. The major purpose of the study is to determine major local issues - past, present, and future - which community leaders feel are important to the development of the community, and which can be related to the siting of the nuclear facility. Other supporting information to be gathered deals with leadership values, expectations of future events, and the performance of the TVA social impact mitigation plan.

The determination of major issues is important in the selection of impact variables for monitoring social impacts. Additionally, issue identification helps to determine which impacts are anticipated by. the community leaders - and thus can be addressed at an early stage - and which issues arise as a reaction to an impact - and thus must be addressed quickly. An example of an anticipated issue might be service capacity or zoning; unanticipated problems may arise from traffic problems, underestimation of inmigrants, or housing shortages. The monitoring of impact variables will also serve to evaluate the effectiveness of local policy decisions, whether in anticipation of or in reaction to significant social impacts. 
A second purpose of this study, related to the determination of important issues, is to determine the general value orientations of the leadership of the community. Ascertaining which community orientations are valued above others will help in explaining why some issues arise instead of others. Additionally, the configuration of values might vary from community to community, and the difference between the nuclear and coal community cases will be an important variable to consider in future analyses.

A third purpose of this study is to get some idea of differences between leaders and citizens in expectations of future events and general support and opposition to the facility. While general attitudes and opinions for the community at large were gathered in 1975 (Schuller, et a1., 1975; Sundstrom, et a1., 1977), some indication of leadership orientations is necessary to indicate whether the leaders and community influentials accurately reflect or adequately estimate general community feelings.

Finally, some general information is required as to the performance of the TVA in assisting the local impact area in mitigating some anticipated construction related impacts. Since the leadership has been involved in various aspects of negotiation and administration of this phase of the TVA program, this rating of the responsiveness and effectiveness of the plan is necessary as a baseline for evaluation over time (detalled descriptions of this and other mitigation plans are presented in Gilliss, 1976 and Peelle, 1977). 


\section{Method}

The first step in this analysis, is to determine the membership of the community leaders. As has been discussed elsewhere (Dahl, 1966; Agger, et a1., 1964; Polsby, 1963), those individuals who influence decisions do not necessarily occupy formal decision-making positions in the local government. Some methods do exist for determining this group, and these methods are used in the following analysis (cf. Laumann and Pappi, 1976).

A list of potential community leaders was gathered by the research staff familiar with the community setting, utilizing public documents. Public documents included the minutes of the (county) Quarterly Court meetings for the past four years, an equivalent volume of City Commission documents, and local newspapers. Care was taken to include as many important sectors of community life as possible. Thus, the list was required to have representatives not only from formal governmental bodies, such as the Quarterly Court, City Commission, School Board, and Planning Commission, but also from the media, downtown businesses, financial institutions, county manufacturing concerns and fraternal and civic clubs. The combination of activity and sector requirements led to an initial list composed of 69 individuals.

The second stage involved the use of community informants to cut down the list to manageable size and to check for notable omissions. These off-the-record discussions led to the elimination of 27 individuals, leaving a total of 42 . There was general agreement from community leaders with our efforts, with one or two exceptions. Only one individual was felt to have been inadvertently left off the list, and that individual 
was added subsequently. Additionally, a substitute in one opinion sector was called upon, due to the unavailability of the original individual.

Thus, a final list of 44 individuals was developed. Of the 44 on the list, 37 were contacted and agreed to help us gather information about the community. Two outright refusals were encountered, and five individuals were unavailable but agreed, in principle, to assist us in the future if a mutually acceptable time could be agreed upon.

Facilitating the task of developing a list of leaders was the anticipated overlap among governmental, business and civic roles, which is usual in small communities (Freeman, 1968; Wildavsky, 1966; Milbrath, 1965). Of the 37 influentials contacted 26 (70.3\%) hold government office, while 11 do not. Of those holding governmental office, 17 (65.4\%) hold county office, five (19.2\%) hold city office, while four (15.4\%) hold both city and county office. Of the 26 office holders, $20(76.9 \%)$ hold only one office, five (19.2\%) hold two offices, while one individual holds three offices.

The leaders were then asked for information on the "top 5 " influentials" on the list. A clear-cut "core" list of seven individuals emerged as shown in Table 2.

The list of the "top 7" is almost evenly distributed among three important local sectors of community life - government, business, and professions. Governmental positions named (not in order of influence) included the County Judge and Superintendent of Schools, at the county level, and the Mayor at the city level. Professional and business positions included an attorney, a doctor, and two businessmen engaged in banking and land development. 
Table 2. Top Community Leaders

\begin{tabular}{lll}
\hline Leader & $\begin{array}{c}\text { Number of selections } \\
\text { as "top 5" }\end{array}$ & $\begin{array}{l}\text { Primary area } \\
\text { of responsibility }\end{array}$ \\
\hline A & 26 & Local government \\
$B$ & 25 & Local government \\
C & 23 & Professional \\
$D$ & 16 & Business \\
E & 16 & Local government \\
$F$ & 11 & Business \\
G & 10 & Professional \\
\hline
\end{tabular}

4. Results and Discussion

\subsection{Leadership Characteristics}

The leaders present a fairly high socioeconomic status profile. As shown in Table 3 most of the leaders are in high status occupational categories. A majority, (64.2\%) have some college experience, with nine individuals having some kind of advanced training. Reported income was evenly divided between those making under $\$ 25,000$ per year and those making over $\$ 25,000$ per year. However, only one individual reported an income of under $\$ 10,000$, while seven reported incomes of over $\$ 30,000$.

Fraternal or civic club membership is also high among the community leaders with 30 individuals $(81.1 \%)$ belonging to at least one organization. However, eleven individuals belong to two organizations, six belong to three organizations and three belong to four or more organizations. Thus, two-thirds of the influentials have multiple civic or fraternal club 
membership - an expected characteristic of a group of active community leaders. Additionally, $46.7 \%$ of club members $(N=14)$ hold club offices with four individuals holding two or more offices. Organizations most often mentioned include the Chamber of Commerce (12 times), Masons (11), Lions (7), and Kiwanis (6). Other mentions include the American Legion, Quarterback Club, and VFW.

Table 3. Socioeconomic Status Characteristics of Leaders

\section{Occupation}

Professiona1, manager

Business proprietor, independent farmer

White collar (sales, etc.)

Retired, semi-retired, housewife

Total $14(37.8)^{\mathrm{a}}$

$17(45.9)$

$2(5.4)$

$4(10.8)$

$37(99.9)$

Education

High school graduate or less

$14(37.8)$

College attendance

$14(37.8)$

Graduate work

$9(24.3)$

Total

$37(99.9)$

${ }^{a}$ Figures in parentheses indicate percentage. 


\subsection{Leadership Support and Opposition}

Leaders are generally more in favor of the plant than the community at large. Fully $86.1 \%$ of the leaders would permit the construction of the nuclear power plant, with $63.9 \%$ "definitely" in favor and $22.2 \%$ "probably" in favor. Only $8.3 \%$ are opposed, while $5.6 \%$ are undecided. A comparison of the leaders' support and opposition to the plant with our citizen surveys, conducted prior to issuance of the limited work authorization, is presented in Table 4.

Table 4. Support and Opposition to the Hartsville Nuclear Power Plant

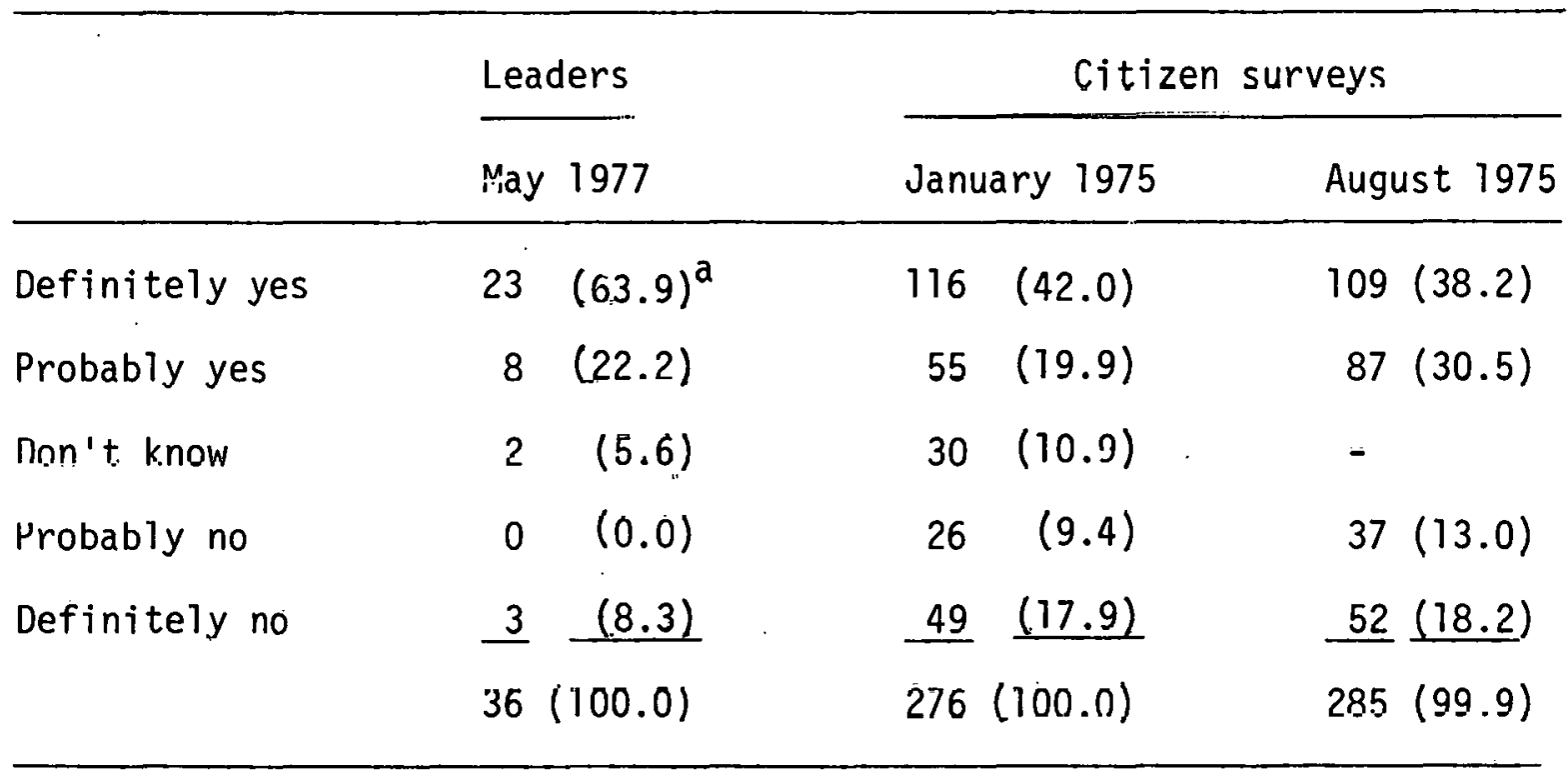

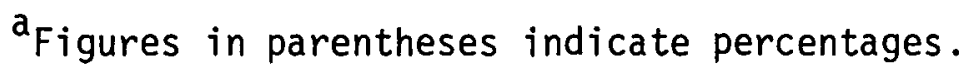

Although the format of the citizen survey response changed from January to August (the "don't know" category was not a choice in the August survey), the citizen support for the plant is significantly less prevalent than the support among community leaders. Table 5 presents the two citizen surveys and the leadership study in a more 
comparable form - with the "don't know" categories eliminated. The differences between the citizen samples and the leadership study are once again highlighted. While the degree of support in the citizen samples was 69.6 percent in January and 68.7 percent in August 1975, the level of support among leaders is 91.1 percent.

Table 5. Adjusted Frequencies for Support and Opposition to the Hartsville Nuclear Power Plant

\begin{tabular}{|c|c|c|c|c|c|c|}
\hline \multirow[b]{3}{*}{ Definitely yes } & \multirow{2}{*}{\multicolumn{2}{|c|}{$\frac{\text { Leaders }}{\text { May } 1977}$}} & \multicolumn{4}{|c|}{ Citizen surveys } \\
\hline & & & \multicolumn{2}{|c|}{ January 1975} & \multicolumn{2}{|c|}{ August 1975} \\
\hline & & $(67.6)^{\mathrm{a}}$ & 116 & $(47.2)$ & 109 & $(38.2)$ \\
\hline Probably yes & 8 & $(23.5)$ & 55 & $(22.4)$ & 87 & $(30.5)$ \\
\hline Probably no & 0 & $(0.0)$ & 26 & $(10.6)$ & 37 & $(13.0)$ \\
\hline Definitely no & 3 & $(8.8)$ & 49 & (19.9) & 52 & $(18.2)$ \\
\hline Total & 34 & $(99.9)$ & 246 & $(100.0)$ & 285 & $(99.9)$ \\
\hline
\end{tabular}

${ }^{a}$ Figures in parentheses indicate percentage.

Some questions could be raised regarding our comparison of leaders support and opposition to citizen surveys taken almost two years earlier. In the intervening time period, it could be argued, the plant had been given various site-preparation permits, the labor force had grown to about 2,000 individuals, and some social and economic impacts had occurred in the Hartsville/Trousdale County area. Given these circumstances, it could be argued that current citizen attitudes would be different from 1975 attitudes and any comparisons using those attitudes might be misleading. 
While the above-mentioned argument certainly has merit, strong counter arguments can be made. First, it is expected that government and business leaders will be more supportive of nuclear power than the general population.. National surveys conducted by Louis Harris Associates, for Ebasco Services, Inc., in 1975 and 1976 show that support among governmental and business leaders for building more nuclear power plants in the United States ranged to 92 percent in 1975 and 93 percent in 1976 (Ebasco II, p. 22). Thus, our findings of 80.1 percent support (froiil Table 4) or 91.1 percent from "adjusted" support (Table 5) compare favorably with the national surveys. More important, however, is the concept of stability of attitudes over time and the implications this concept has for our comparisons. Basically, psychological research has shown a strong perseverance of prior beliefs, even in the face of contradictory evidence (Slovic, 1977; Ross, 1977). Once beliefs are formed, new information tends to be filtered through these beliefs, with the result that supportive information is accepted and contradictory evidence is dismissed, or new information is adjusted to conform to prior beliefs. Thus, for example, a nuclear opponent would use the Brown's Ferry incident as evidence to support his belief in the risk associated with nuclear power, while a supporter might use the same information to reinforce his confidence in the ability of the industry to rise to the occasion and contain potentially dangerous incidents. There is both theoretical and empirical evidence to support the hypothesis that attitudes tend to be stable over time. Thus, appropriate comparisons can be made between the study done in 1977, and two surveys done in 1975, with the expectation that citizen attitudes would have a similar distribution in 1977. The perseverance-of-attitudes hypothesis will be tested with our next general attitude survey, to be conducted in late 1977 . 
Two statistical findings from our studies further strengthen the stability or perseverance-of-beliefs hypothesis. First, the correlation between the two citizen surveys in 1975, even with maintenance of the "don't know". category, is 0.76 (Sundstrom, et a1., 1977). With the "don't know" category eliminated, the gamma index of association is an even higher 0.85 , indicating a strong degree of stability between the first two citizen surveys. Finally, only eight community leaders indicate that they have changed their opinions about the plant, over the past year or two. Only one of the eight changed general categories ("support," "oppose," or "undecided") going from "opposed" to "undecided." of the remaining changes, three have become "more in favor," two "less in favor" and one "more opposed."

Community leaders tend to give realistic estimates of public (Hartsville/Trousdale County) support for the plant but significantly underestimate the degree of community opposition. As shown in Table 6 , the average estimate of citizen support for the plant is $70.7 \%$, the average estimate for citizen opposition is $13.2 \%$, and the average estimate for the proportion of citizens undecided is $15.9 \%$.

Table 6. Leaders' Estimates of Citizen Support of Nuclear Power Plant ${ }^{a}$

\begin{tabular}{lcc}
\hline & $\begin{array}{c}\text { Mean } \\
\text { estimate }\end{array}$ & $\begin{array}{c}\text { Range (percent) } \\
\text { of estimate }\end{array}$ \\
\hline In favor & $70.7 \%$ & $(30-59)$ \\
Opposed & $13.2 \%$ & $(1-60)$ \\
Undecided & $15.9 \%$ & $(0-50)$ \\
\hline
\end{tabular}

${ }^{\mathrm{a}}$ See Table 4 for a comparison of actual citizen attitudes. 
It is most interesting that the proportion of opposition is underestimated, since in both the January and August surveys, the proportion of citizen opposition ranged from $27-31 \%$, in spite of the "undecided" category not being included in the August survey. Apparently, when forced to choose "support" or "opposition," undecided citizens chose "support" by almost a 2-to-1 majority.

A comparison of leaders' estimates of public opinion can be drawn from the Ebasco surveys which ask business and political leaders to estimate public opinion on nuclear power plant safety. While only $18 \%$ of the public says nuclear power is "not so safe" or "dangerous," political and business leaders estimate $38-44 \%$ of the public will be in these categories (Ebasco I, p. 63). Thus, we might assume that leaders tend to overestimate the public's safety concerns, and thus overestimate the degree of public opposition to nuclear power. This hypothesis may be supported by the increasing visibility in the media of a vocal opposition, which may be having a significant impact upon the perceptions of support and opposition by business and political leaders. Information gathered by the current study at Hartsville, however, as mentioned earlier, shows that support for the facility is accurately estimated, while the degree of opposition is largely underestimated. Some insight to leaders' underestimation of opposition can be gained from leaders' distinctions between support/opposition and acceptance. Discussions with community leaders elicited a number of statements to the effect that regardless of the distribution of support and opposition in the community, invariably the community has accepted the facility. It is this fact that may have enhanced community 
leaders' estimates of community support and downplayed the perceived weight of opposition. This may have been further exacerbated by the fact that the construction permit for a nuclear facility had been issued in April 1977 (although some environmental challenges are still under way). The significance of this finding may lie in the context of future decisions which are based upon perceptions of individual and community support, rather than decisions which might alleviate or address the sources of community opposition.

\subsection{Significant Local Issues}

An important aspect of this study was to determine important local issues arising from the construction of the plant, and to determine significant trends or directions for future issues - which new ones might be expected to arise, and which might be expected to continue to be problems. An interesting and illuminating set of issues emerged from information given by local leaders. Information was gathered on important issues in the recent past, current important issues, and issues expected to face the area in the near future. A list of issues mentioned is presented in Table 7. Three interesting conclusions can be drawn from the list. First, considering past community issues, the community leaders find it easy to be specific with regard to important areas, i.e., the community auditorium, the zoning ordinance, and the proposed extension of the railroad spur. Second, current issues of more immediate salience for the community deal more generally with the housing shortage and plant-related traffic problems. However, as with past issues, there is a strong underlying concern with basic services (sewer, water, planning, zoning). Finally, future issues, while still concerned with 
direct plant-related problems such as housing and traffic, begin to raise more general growth issues - growth and planning, jobs (keeping workers in the area.) and taxes (fiscal capacity).

Table 7. Important Issues Facing the Local Area

\begin{tabular}{|c|c|c|}
\hline Past Issues & Current Issues & Future Issues \\
\hline Water $(6)^{\mathrm{a}}$ & Housing (18.) & Housing (10) \\
\hline Community Auditorium (6) & Traffic (13) & Traffic (8) \\
\hline Housing (6) & Water (4) & $\begin{array}{l}\text { Growth and } \\
\text { Planning (7) }\end{array}$ \\
\hline The Nuclear Power Plant (5) & Services (3) & Jobs (4) \\
\hline Sewers (5) & Planning (3) & Taxes (3) \\
\hline Zoning (3) & Miscellaneous Isșues (13) & $\begin{array}{l}\text { Miscellaneous } \\
\text { Issues (11) }\end{array}$ \\
\hline \multicolumn{3}{|l|}{ Railroad Extension (3) } \\
\hline Miscellaneous Issues (11) & & \\
\hline
\end{tabular}

${ }^{a}$ Figures in parentheses indicate the number of times. the specific issue was mentioned.

\subsection{Community Values}

The value orientations of community leaders are very important in indicating possible directions for future decisions. If influentials value economic development over environmental integrity, it can be hypothesized that policy alternatives which impact both of these values will be decided in favor of economic development, even at the expense of environmetal quality. The community influentials provided information 
on the ranking of a set of eight general value orientations. Rankings were weighted ( a score of 1 for "most important" to 8 for "least important") and appear in Table 8 in order of importance for all community influentials.

Table 8. Community Value Orientation Ranking

Rank Value

\begin{tabular}{ll}
\hline & Promotion of housing development for all residents (92) \\
2 & Maintenance and extension of quality of life (93) \\
3 & Safeguarding conditions to guarantee economic growth (129) \\
4 & Insuring efficient and fair community admininstration (141) \\
5 & Promotion of active citizen participation (162) \\
6 & Preserving the environmental quality of the area (194) \\
7 & Preservation of cultural heritage and traditional values (236) \\
8 & Avoidance of conflicts between population groups (251) \\
\hline
\end{tabular}

$a_{\text {Figures in parenthesis indicate cumulative score. Lower score indicates }}$ greater importance.

As these rankings indicate, the general values of "quality of life" (of which housing development is a part) are most important for community influentials. The fact that housing ranks slightly higher than quality of life is indicative of the specific perceived housing problem within the community as a result of the nuclear power plant activity.

The value rankings should reflect individual involvement in community ' issues in the general "quality of life" area. As we have seen earlier, when asked about significant issues the influentials' concerns generally 
centered around services, especially in past and current issues. The concern with quality of life, however, is most strongly evidenced by issues in which the leaders have themselves specifically been involved. As shown in Table 9, these issues strongly reflect the "quality of life" orientation. In addition to previously mentioned issues of water, sewers and housing, community influentials were involved in schoolrelated issues, recreation problems, and the auditorium question.

Table 9. Involvement in Specific Issues

Issues Number of times mentioned

Schools

Water 7

Recreation 6

Housing 6

Zoning 4

Sewers 4

Auditorium 3

Miscellaneous issues

2

\subsection{IVA Mitigation Plan}

The Tennessee Valley Authority, as a public utility, does not pay taxes to the community or county on its land or facilities (it does make in-lieu-of-tax payments to the state, some of which eventually returns to the county). It has been estimated that the current taxes on the 
approximately 2000 acres (unimproved) currently removed from the tax rolls would be about $\$ 2200$ per year, while taxes on the completed facility, if privately owned, would amount to some $\$ 22,000,000$. The TVA has agreed, as part of its construction license, to provide funds for mitigation of anticipated impacts upon the Hartsville/Trousdale County area, as part of its general mitigation plan to assist communities in construction-related impact management where normal (tax) funds would not be available. The impact area is defined as including the five-counties surrounding the plant (Trousdale, Sumner, Macon, Smith, and Wilson). Assistance from TVA is to cover the following major areas:

1. Reduction in number of movers: this plan calls for recruitment and training of local residents, and establishment of an employee transportation system.

2. Planning and coordination: this includes the hiring of a full-time project coordinator, establishment of a Hartsville Project Area Coordinating Council to deal with common area problems, encouragement of local planning commissions and TVA technical assistance to local governing bodies and planning commissions.

3. Housing: this includes assistance in mobile home regulation and financial assistance for mobile home planning.

4. Education: this includes financial assistance for capital equipment purchase, including school buses, temporary classrooms and equipment.

5. Water and sewer facilities: this is directed primarily at assistance for water facilities in Smith County and other financial assistance for temporary sewer facilities. 
6. Health and medical services: this includes on-site ambulance services, establishment of a primary health care center in Hartsville, and assistance for staff salaries in the Smith County Health Department.

As can be expected, most of the community leaders $(81.1 \%)$ were familiar with the mitigation plan. Of those who were familiar with the plan, only one individual considered the plan unfair or inadequate. All of the mitigation sub-areas were generally judged as being either good or adequate by the influentials with the exception of the employee housing category which $46.4 \%$ rated as bad, $25.0 \%$ as adequate, and $28.6 \%$ as good. Currently, two trailer parks are being constructed in the plant area, with one 88-pad site located in Hartsville itself. This park is expected to be ready for occupancy sometime in 1977. When asked what areas TVA may have overlooked in the mitigation plan, six individuals suggested that TVA should have provided more help in general, three suggested that more assistance with the traffic problem should be provided, and other miscellaneous suggestions were offered. Most of the leaders (22 individuals) had no suggestions to offer.

\subsection{Community Satisfaction}

Given the interest in specific issues previously mentioned and the rating of TVA assistance in the local area, it was necessary to gather information as to the adequacy of various areas of community life, including public services. Results presented in Table 10 show two areas were rated as being inadequate - housing and recreation. The housing problem is a recurrent theme in leaders ratings of important issues (Table 7), TVA mitigation strategies, and individual involvement 
(Table 9). Recreation and entertainment is rated as inadequate, but it is not considered a major issue (although some leaders reported being involved in trying to solve this problem). Borderline areas include sewer and water, job training programs and citizen involvement in local decision making. It is interesting to note that no area is rated as "superior," although police protection tends toward that area.

Table 10. Adequacy of Various Areas of Community life

\section{Area}

Rating

Fire protection

Adequate

Sewer and Water

Adequa te-Inadequate

Housing

Inadqua te

Adult education

Adequate

Public schools

Adequate

Health and social welfare

Adequate

Police protection

Adequate

Planning and zoning

Adequate

Job training

Adequate-Inadequate

Citizen involvement in local decision making

Adequate-Inadequate

Growth of the local economy

Adequate

Recreation and entertainment

Inadequate 


\subsection{Expectations of Future Occurrences}

The construction of any large facility can bring a wide range of impacts upon a community. Some of these impacts can be anticipated and dealt with at an early stage as the TVA mitigation plan is proposing to do. Other events may be anticipated but not acted upon until and unless they occur. Community leaders, like their citizen counterparts, (Schuller, et al., 1975; Sundstrom, et al., 1977) tend to see economic benefits (EB) and the disruptive effects of community growth (DECG) as likely to occur. As shown in Table 11 , economic benefits can include such items as more and better paying jobs, increased land values, and industrial development. Growth-related social disruptions may include traffic congestion, increased noise and crime, and housing shortages. Again, as with their citizen counterparts, negative environmental impacts (EI) are seen as unlikely to occur.

Table 11. Leaders' Expectations of Future Events

Certain or Likely to Occur
Uni ikely or Impossible to Occur
a. Traffic congestion (DECG)
a. Cheaper electricity
h. Retter paying jobs $(E B)^{b}$.
b. Pollution of old llickory Lake (EI)c
c. Hetter schiouls
d. More stores and increased business
c. Sabotage at the plant (EI) (EB)
e. More noise (DECG)
d. Radiation hazards (EI)
f. Meeting new people
e. More foggy days (EI)
g. More jubs (EB)
h. Housing shortages (DECG)
$i$. Increased land values (EB)
j. Increased crime (DECG)
$k$. Recognition of the town
1. More taverns and bars (DECG)
m. More recreation areas
n. Increased taxes
o. Industrial development (EB)

\footnotetext{
${ }^{a}$ Disruptive Effects of Community Growth.

$b_{\text {Economic Benefits. }}$

$\mathrm{C}_{\text {Environmental Impacts. }}$
} 


\section{Summary and Conclusions}

The major purpose of this report has been to determine the major issues which community leaders feel are, or witl be important for the future development of Hartsville and Trousdale County - site of the TVA Hartsville Nuclear Power Plant. The leadership group of the community was found to be composed primarily of members of the governmental and business sectors of the community. Most held some elective or appointive county or city office, and most were members of fraternal or civic organizations, with multiple membership being the rule, rather than the exception. From the information gathered from these leaders, it was found that plantrelated issues, such as housing availability and traffic congestion, predominate in estimations of current problems. These issues are expected to continue to be important in the future, and new issues dealing with growth and planning, employment and taxation are expected to arise.

In comparison to general citizen attitudes, leaders are generally more supportive of the nuclear power plant. While approximately twothirds of the citizens of the area would permit construction of the nuclear power plant, approximately ninety percent of the leaders would do so. These results seem to be consistent with national surveys, although as discussed earlier, our citizen and leadership studies were taken some time apart, and results might be open to some questions of reliability on those grounds.

Community leaders seem to estimate correctly the degree of community support for the plant, but tend to underestimate the degree of community opposition. Again, because of the time difference between the citizen 
surveys and the leadership study, some changes in citizen attitudes may have occurred, although other research indicates that these changes would be minor.

In general, leaders value very highly the quality of life in the area, with economic development, general governmental administration and participation next in importance. This information will be very useful in future research in the prediction and explanation of why certain decisions are made while others are not.

As with. the community sample, leaders in Hartsville and Trousdale County expect economic benefits to occur, and expect some social disruption to accompany the economic development. Environmental impacts such as water pollution and radiation hazards are seen as extremely unlikely. Community leaders support the TVA social impacts mitigation plan in all areas except that of employee housing. The effort in the housing area is felt to be inadequate at the present time.

Future research will concentrate upon the actual decisions which are made in the community in the general areas of revenues and expenditures, planning, and community services support and development. The relationships of these decisions to the nuclear power plant, and to leaders' expectations will be analyzed, and the effectiveness of the decisions in meeting their goals will be evaluated. The experience of Hartsville and Trousdale County in dealing with the problems associated with energy-related facility construction and operation will help other communities in assessing their potential for hosting similar facilities, and will assist the federal government in the planning and implementation of future energy development policies. 


\section{Bibliography}

1. Donald T. Campbell and Julian C. Stanley, Experimental and QuasiExperimental Designs for Research, Chicago: Rand McNa17y, 1966.

2. Robert A. Dah 1, Who Governs? New Haven: Yale University Press, 1963.

3. Ebasco I, A Survey of Public and Leadership Attitudes Toward Nuclear Power Deve Topment in the United States, conducted for Ebasco Services, Inc., by Louis Harris and Associates Inc., Study Number 2515, August 1975.

4. Ebasco II, Survey II of Public and Leadership Attitudes Toward Nuclear Power Development in the United States, conducted for Ebasco Services, Inc., by Louis Harris and Associates, Inc., Study Number 2628, November 1976.

5. Linton C. Freeman, Patterns of Local Community Leadership, New York: Bobbs-Merrill, 1968.

6. Edward Gilliss, "Mitigation Plans for Social Impacts of Construction and Operation of Large Energy Conversion Facilities: A Comparative Analysis," unpublished manuscript, Oak Ridge National Laboratory, December 1976.

7. Edward 0. Laumann and Franz U. Pappi, Networks of Collective Action, New York: Academic Press, 1976.

8. Lester W. Milbrath, Political Participation, Chicago: Rand McNally, 1965.

9. Elizabeth Peelle, "Internalizing Social Costs in Power Plant Siting: Some Examples for Coal and Nuclear Power Plants in the United States," unpublished manuscript presented at the International Meeting of the American Nuclear Society, November 1976.

10. Nelson W. Polsby, Community Power and Political Theory, New Haven: Yale University Press, 1963.

11. Lee Ross, "The Intuitive Psychologist and His Shortcomings: Distortions in the Attribution Process," in L. Berkowitz, (ed.), Advances in Experimental Social Psychology, in press.

12. C. R. Schuller, J. R. Fowler, T. J. Mattingly, Jr., E. D. Sundstrom, J. W. Lounsbury, E. M. Passino, D. A. Dowell and B. J. Hutton, Citizens' Views About the Proposed Hartsville Nuclear Power Plant: Preliminary Report of Potential Social Impacts, ORIL/RUS-3, Oak Ridge National Laboratory, Oak Ridge, Tenn., May 1975. 
13. Paul Slovic, Perception and Acceptability of Risk from Nuclear Power and Al ternative Energy Sources, unpublished manuscript, Decision Research, Inc., Eugene, OR, March 1977.

14. E. D. Sundstrom, L. J. Costomiris, R. C. DeVault, D. A. Dowe11, J. W. Lounsbury, T. J. Mattingly, Jr., E. M. Passino, and E. Peelle, Citizens' Views About the Proposed Hartsville Nuclear Power Plant: A Survey of Residents ' Perceptions in Auqust, 1975, ORNL/TM-5801, Oak Ridge National Laboratory, Oak Ridge, Tenn., May 1977.

15. Aaron Wildavsky, Leadership in a Small Town, Totowa, N.u.: the Bedminster Press, 1966. 
ORNL/TM-5997

Internal Distribution

1. S. E. Beall

2. D. J. Bjornstad

3. C. R. Boston

4-28. B. H. Bronfman

29. R. S. Carlsmith

30. L. G. Berry

31. C. Chern

32. L. J. Costomiris

33. T. Cowan

34. R. C. DeVault

35. R. M. Davis

36. W. Fulkerson

37. E. A. Hirst

38. N. Hinkle

39. M. J. Ketelle

40. C. R. Kerley

41. R. B. Honea

42. A. S. Loebl

43. J. W. Lounsbury

44. L. A. Martin

45. T. J. Mattingly, Jr.

46. J. McWherter
47. E. Peelle

48. H. Postma

49. B. J. Purdy

50. A. S. Quist

51. P. L. Rice

52. M. W. Rosenthal

53. T. Row

54. R. M. Rush

55. M. A. Shields

56. R. L. Spore

57. E. D. Sundstrom

58. R. E. Thoma

59. A. H. Voelker

60. D. Vogt

61. T. J. Wilbanks

62. H. E. Zittel

83-64. Central Research Library

65. Document Reference Section

66-67. Laboratory Records

68. Laboratory Records (RC)

69. ORNL Patent Office

70-202. Regional and Urban Studies

Section, Energy Division

\section{External Distribution}

203. Director, Research.and Technical Support Division, ERDA-ORO.

204-230. Technical Information Center, ERDA-OR

231-1000. Regional and Urban Studies Distribution, Social Impact Assessment Group. 